\title{
Bombyx mori nucleopolyhedrovirus (BmNPV) Bm64 is required for BV production and per os infection
}

\author{
Lin Chen ${ }^{1,2}$, Yunwang Shen ${ }^{2}$, Rui Yang ${ }^{2}$, Xiaofeng $\mathrm{Wu}^{2}$, Wenjun $\mathrm{Hu}^{1}$ and Guoxin Shen ${ }^{1 *}$
}

\begin{abstract}
Background: Bombyx mori nucleopolyhedrovirus (BmNPV) orf64 (Bm64, a homologue of ac78) is a core baculovirus gene. Recently, Li et al. reported that Ac78 was not essential for budded viruses (BVs) production and occlusion-derived viruses (ODVs) formation (Virus Res 191:70-82, 2014). Conversely, Tao et al. demonstrated that Ac78 was localized to the BV and ODV envelopes and was required for BV production and ODV formation (J Virol 87:8441-50, 2013). In this study, the function of Bm64 was characterized to determine the role of Bm64 in the BmNPV infection cycle.

Method: The temporal expression of Bm64 was examined using total RNA extracted from BmNPV-infected BmN cells at different time points by reverse-transcription PCR (RT-PCR) and 5' RACE analysis. To determine the functions of Bm64 in viral replication and the viral phenotype throughout the viral life cycle, a deletion virus $\left(\mathrm{vBm}^{64 \mathrm{KO}}\right)$ was generated via homologous recombination in Escherichia coli. Viral replication and BV production were determined by real-time PCR. Electron microscopy was used to detect virion morphogenesis. The subcellular localization of Bm64 was determined by microscopy, and per os infectivity was used to determine its role in the baculovirus oral infection cycle.

Results: Viral plaque and titer assay results showed that a few infectious BVs were produced by $\mathrm{BBm}^{64 \mathrm{KO}}$, suggesting that deletion of Bm64 affected BV production. Viral DNA replication was detected and polyhedra were observed in $\mathrm{VBm}^{64 \mathrm{KO}}$-transfected cells. Microscopy analysis revealed that Bm64 was predominantly localized to the ring zone of the nuclei during the infection cycle. Electron microscopy showed that Bm64 was not essential for the formation of ODVs or the subsequent occlusion of ODV into polyhedra. The per os infectivity results showed that the polyhedra of $\mathrm{vBm}^{64 K O}$ were unable to infect silkworm larvae.
\end{abstract}

Conclusion: In conclusion, our results suggest that Bm64 plays an important role in BV production and per os infection, but is not required for viral DNA replication or ODV maturation.

Keywords: Bombyx mori nucleopolyhedrovirus (BmNPV), Bm64, Budded virus production, Occlusion-derived virus formation, per os infection

\section{Background}

The family Baculoviridae is composed of insect-specific DNA viruses containing covalently closed, doublestranded DNA genomes ranging from 80 to $180 \mathrm{k}$ bp with 90 to 180 open reading frames (ORFs). This viral family is divided into four genera (Alphabaculovirus, Betabaculovirus, Gammabaculovirus and Deltabaculovirus) that include lepidopteran-specific baculoviruses, lepidopteran-

\footnotetext{
* Correspondence: guoxin.shen@ttu.edu

${ }^{1}$ Sericultural Research Institute, Zhejiang Academy of Agricultural Sciences, Hangzhou 310021, China

Full list of author information is available at the end of the article
}

specific granuloviruses, hymenopteran-specific baculoviruses, and dipteran-specific baculoviruses, respectively [1]. The viral life cycle presents a biphasic infection process generating progeny with two different phenotypes: budded viruses (BVs), which are produced at the initial stage of the multiplication cycle that are responsible for systemic infection inside the insect host $[2,3]$ and occlusion-derived viruses (ODVs) produced in the late stage of the cycle that are required for the primary infection that takes place in the midgut epithelium cells of the insect host $[4,5]$. Finally, mature ODVs are occluded in a

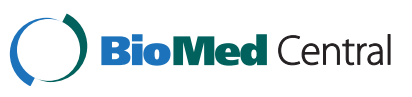

(c) 2015 Chen et al. Open Access This article is distributed under the terms of the Creative Commons Attribution 4.0 International License (http://creativecommons.org/licenses/by/4.0/), which permits unrestricted use, distribution, and reproduction in any medium, provided you give appropriate credit to the original author(s) and the source, provide a link to the Creative Commons license, and indicate if changes were made. The Creative Commons Public Domain Dedication waiver (http://creativecommons.org/publicdomain/zero/1.0/) applies to the data made available in this article, unless otherwise stated. 
protein matrix to form polyhedra that protect the ODVs from the environment [6].

The Bombyx mori nucleopolyhedrovirus (BmNPV) orf64 (Bm64) encodes a gene product 110 amino acids in length [7]. Its homologs are present in all of the sequenced baculovirus genomes and are assigned as a baculovirus core gene $[8,9]$. A recent proteomic study determined the protein composition of ODVs of HearNPV and concluded that the homolog of Bm64 was associated with ODVs [10]. Recently, the function of the Bm64 homologue Autographa californica multiple nucleopolyhedrovirus (AcMNPV) ac78 was analyzed $[11,12]$. Tao et al. demonstrated that Ac78 was localized in the BV and ODV envelopes and was required for BV production and ODV formation [12]. A similar phenotype was detected during the investigation of the Bm64 homologue Helicoverpa armigera nucleopolyhedrovirus ha72. HA72 was demonstrated to be required for $\mathrm{BV}$ production and ODV embedding. Moreover, the IPLKL motif at the $\mathrm{N}$ terminus was shown to play an important role in its function [13]. More recently, Li et al. found that Ac78 was not essential for BV production and ODV formation [11], which was a contradictory result. To date, there is no consensus concerning the function of the Bm64 homologue in the viral infection cycle (Additional file 1: Table S1).

Although interruption of Bm64 resulted in a single-cell infection phenotype [14], the function of $B m 64$ in viral infection was not determined in detail. To investigate the role of Bm64 during BmNPV replication, we generated a Bm64-deletion virus $\left(\mathrm{vBm}^{64 \mathrm{KO}}\right)$ in Escherichia coli through homologous recombination. The Bm64deletion decreases BV production but has little effects on viral DNA replication and very late protein expression. Electron micrographs revealed that mature ODVs were detected in the nuclei of $\mathrm{vBm}^{64 \mathrm{KO}}$-transfected cells. Per os infection assay results showed that the polyhedra of $\mathrm{vBm}^{64 K O}$ were unable to infect silkworm 5 th instar larvae. Our results suggested that Bm64 played an important role in BV production and per os infection but was not required for viral DNA replication or ODV maturation.

\section{Results}

\section{Bm64 transcripts in BmN cells after BmNPV infection}

For the initial characterization, $B m 64$ temporal expression was examined using total RNA extracted from BmNPVinfected $\mathrm{BmN}$ cells at different time points by reversetranscription PCR (RT-PCR) and 5' RACE analysis. The RT-PCR analyses showed that the 333 bp Bm64-specific transcripts were first detected $6 \mathrm{~h}$ p.i. (hours postinfection), steadily increased up to $72 \mathrm{~h}$ p.i., and remained detectable at 96 h p.i. (Fig. 1a).

A search of the $200 \mathrm{bp} \mathrm{5}$ 'to the predicted start codon of the Bm64 ORF (ATG) showed the presence of two contiguous late promoter TAAG elements located at positions -12 and -93.5 RACE analysis revealed that the Bm64 mRNA initiated from the G of TTAAG, indicating that the upstream promoter element (-93) was used for Bm64 transcription (Fig. 1b). The results agreed with the baculovirus transcriptional data [15].

\section{Construction and analysis of the wild type, Bm64 knockout and repair BmNPV bacmids}

The Bm64-null mutant $\left(\mathrm{bBm}^{64 \mathrm{KO}}\right)$ was constructed via the $\lambda$ Red recombination system as previously described [16]. To examine the effect of the Bm64 deletion on polyhedra morphogenesis and to facilitate the examination of virus infection, the polyhedrin and $g f p$ genes were transposed into the polyhedrin locus of $\mathrm{bBm}^{64 \mathrm{KO}}$ to generate $v \mathrm{Bm}^{64 \mathrm{KO}}$ (Fig. 2a). As a positive control, $\mathrm{vBm}$ was also generated by inserting polyhedrin and $g f p$ into the polyhedrin locus of the BmNPV bacmid. To confirm that the phenotype resulting from the Bm64 knockout was not due to genomic effects, we constructed a repair bacmid $\left(\mathrm{vBm}^{64 \mathrm{RE}}\right)$ containing the Bm64 ORF driven by its native promoter in addition to the polyhedrin and $g f p$ sequences.

To determine the effect of the Bm64 deletion on viral replication, $\mathrm{BmN}$ cells were transfected with $\mathrm{vBm}$, $\mathrm{vBm}^{64 \mathrm{KO}}$, or $\mathrm{vBm}^{64 \mathrm{RE}}$. The transfected cells were monitored by fluorescence microscopy. No differences in the numbers of GFP-positive cells were observed among these three samples $36 \mathrm{~h}$ p.t. (hours post-transfection), indicating relatively equal transfection levels and efficiencies (Fig. 2b). By 96 h p.t., wide-spread fluorescence

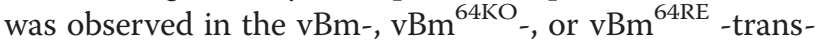
fected cells.

Light microscopy analysis revealed that polyhedra appeared in all three construct-transfected cells at $96 \mathrm{~h}$ p.t. (Fig. 2c), suggesting that viral replication proceeded to very late time points. The bacmid transfection experiments showed that deletion of Bm64 did not affect OB formation.

Polyhedra were detected in nearly all cells transfected with $\mathrm{vBm}$ or $\mathrm{vBm}^{64 \mathrm{RE}}$. However, only $50 \%$ of $\mathrm{vBm}^{64 \mathrm{KO}}$ transfected cells contained polyhedra (Fig. 2c), suggesting that deletion of $B m 64$ affected virus infectivity. To monitor the effect of the Bm64 deletion on viral spread, a GFP fluorescent plaque assay was performed on cell monolayers transfected with $\mathrm{vBm}, \mathrm{vBm}^{64 \mathrm{KO}}$, or $\mathrm{vBm}^{64 \mathrm{RE}}$. Only the diameters of well-isolated plaques were measured (16 for each virus) at $72 \mathrm{~h}$ p.t.. Both $\mathrm{vBm}$ and $\mathrm{vBm}^{64 \mathrm{RE}}$ produced large plaques in the $\mathrm{BmN}$ cells, with mean diameters of $262.7 \pm 14.32 \mu \mathrm{m}$ and $264.3 \pm 13.94 \mu \mathrm{m}$, respectively (Fig. $2 \mathrm{~d}$ ). The $\mathrm{vBm}^{64 \mathrm{KO}}$ plaques were significantly smaller in size, with a mean diameter of $119.0 \pm$ $10.20 \mu \mathrm{m}$. This result indicated that deletion of $\mathrm{Bm} 64$ affected virus spread. 
A

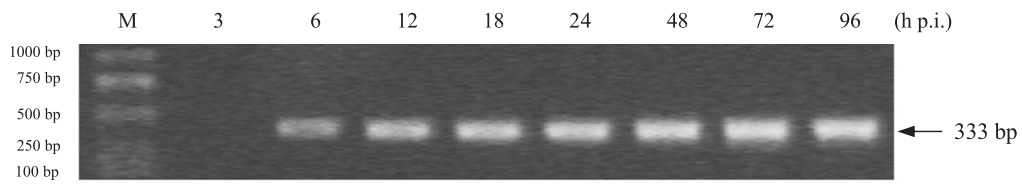

$\mathrm{B}$

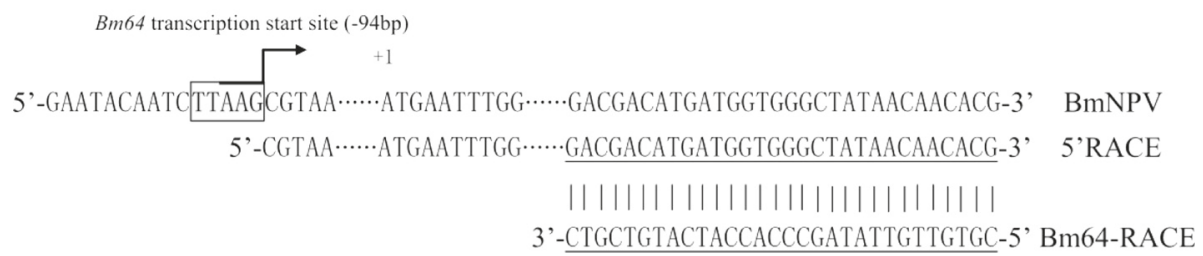

Fig. 1 Transcriptional analysis of Bm64. a RT-PCR analysis of Bm64 transcripts. Total RNAs were extracted from BmNPV-infected BmN cells at the designated time points. The size of the PCR products is indicated on the right. $\mathbf{b} 5^{\prime}$ RACE analysis of the Bm64 transcriptional start site. The sequence derived from the 5'RACE analysis is shown below. The late promoter, TTAAG (boxed), and the transcriptional start site (arrow) are shown. The translational start codon (ATG) is indicated as +1 . The primer Bm64RACE is underlined

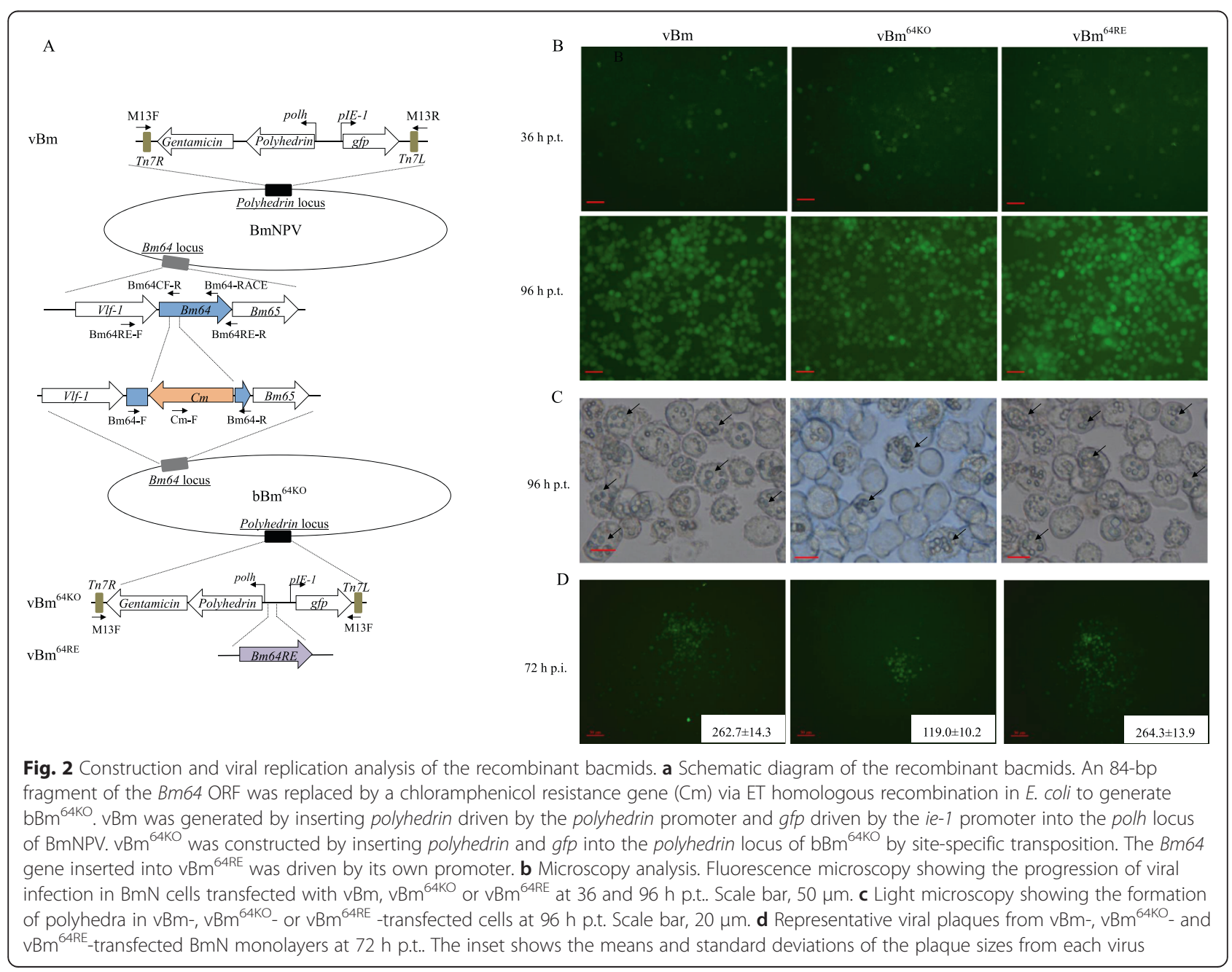


Viral growth curve and viral DNA replication analysis

The viral replication results suggested that the $B m 64$ deletion led to a defect in infectious BV production. To confirm these results and to assess the effect of the $B m 64$ deletion on virus replication, a viral growth curve analysis was performed using $\mathrm{TCID}_{50}$ and $\mathrm{qPCR}$ assays. $\mathrm{BmN}$ cells were infected with the different constructs, and the BV titers were determined by end-point dilution for $\mathrm{TCID}_{50}$ at the selected time points.

Newly produced BVs were detectable at $12 \mathrm{~h}$ p.i. for $\mathrm{vBm}$ or $\mathrm{vBm}^{64 \mathrm{RE}}$. As expected, $\mathrm{BmN}$ cells transfected with $\mathrm{vBm}$ and $\mathrm{vBm}^{64 \mathrm{RE}}$ revealed a normal increase in virus production (Fig. 3a). However, no infectious BVs were detected up to $12 \mathrm{~h}$ p.i. in the $\mathrm{vBm}^{64 \mathrm{KO}}$-infected cells. This result confirmed that Bm64 was required for BV production and viral infection. Furthermore, the Bm64 repair virus was as sufficient in virus production as the WT virus, confirming that the defect in BV production was not due to genomic effects at the deletion site.

End-point dilution assays were used to determine the production of infectious BVs. Additionally, qPCR analysis was performed to detect $\mathrm{BV}$ genomes regardless of infectivity. As expected, a steady increase in BV production was detected up to $96 \mathrm{~h}$ p.i. for both $\mathrm{vBm}$ and $\mathrm{vBm}^{64 \mathrm{RE}}$. In contrast, an increase in BV production was detected from 48 to $96 \mathrm{~h}$ p.i. for $\mathrm{vBm}^{64 \mathrm{KO}}$-infected cells (Fig. 3b). The qPCR results were in agreement with the $\mathrm{TCID}_{50}$ results.

The production of polyhedra (Fig. 2c) suggested that DNA replication occurred in $\mathrm{vBm}^{64 \mathrm{KO}}$-infected cells [17]. To determine whether Bm64 had any impact on viral DNA replication, $\mathrm{qPCR}$ analysis was performed to compare the levels of viral DNA replication in the vBm-, $\mathrm{vBm}^{64 \mathrm{KO}}$-, and $\mathrm{vBm}^{64 \mathrm{RE}}$-infected cells. Equal amounts of
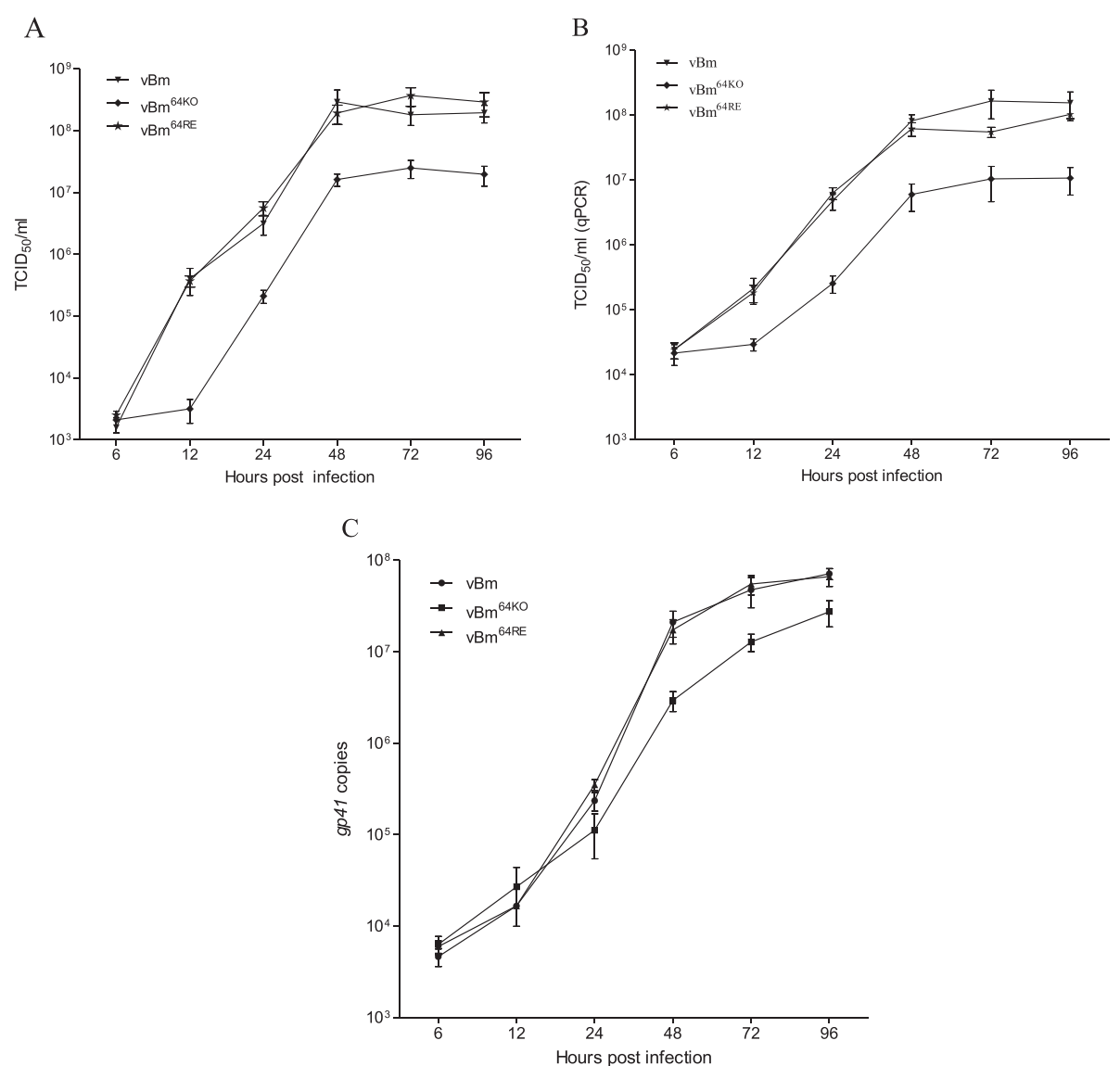

Fig. 3 a Virus growth curves determined by the $T_{C I} D_{50}$ endpoint dilution assays. BmN cells were infected at an $\mathrm{MOl}$ of 3 for each virus, and the supernatants were harvested at the selected time points for the titer assay. Each data point was determined from the average of three independent infections; the error bars represent the standard deviations. $\mathbf{b}$ BV production independent of virion infectivity was determined by quantifying the number of viral genomes by real-time PCR analysis of the supernatants harvested from each bacmid-transfected cell at the designated time points. Each value represents the average of three independent transfections, and the error bars indicate the standard deviations. c Real-time PCR analysis of viral DNA replication. BmN cells were transfected with $\vee B m, \mathrm{VBm}^{64 \mathrm{KO}} \mathrm{or} \mathrm{VBm}^{64 \mathrm{RE}}$. At the designated time points, total intracellular DNA was extracted, digested with the restriction enzyme Dpn I to eliminate input bacmid DNA, and analyzed by real-time PCR. The graph shows the results of three independent replication assays, with error bars indicating the standard deviations 
infected $\mathrm{BmN}$ cells were collected at the designated time points; then, cell lysates were prepared and total DNA was extracted and subjected to qPCR (Fig. 3c). The results showed that all of the viruses were present at comparable levels up to $24 \mathrm{~h}$ p.i.. For $\mathrm{vBm}$ and $\mathrm{vBm}{ }^{64 \mathrm{R}}$, the DNA replication levels continued increasing from $24 \mathrm{~h}$ p.i. and reached plateaus at $72 \mathrm{~h}$ p.i., correlating with the spread of the infection due to the production of BVs. For $\mathrm{vBm}^{64 \mathrm{KO}}$, DNA synthesis increased from $24 \mathrm{~h}$ p.i. and by $96 \mathrm{~h}$ p.i. the replication level was similar to $\mathrm{vBm}^{64 \mathrm{RE}}$. This result was consistent with the viral replication assays (Fig. 2b).

Electron microscopy analysis of $\mathrm{vBm}-, \mathrm{vBm}^{64 \mathrm{KO}}-$, and $\mathrm{vBm}^{64 R E}$-infected cells

To determine whether the Bm64 deletion affected virion morphogenesis, electron microscopy analysis was performed with thin sections generated from virus-infected cells at $72 \mathrm{~h}$ p.i.. Observations of $\mathrm{vBm}^{64 \mathrm{KO}}$-infected cells were morphologically indistinguishable from observations of cells transfected with $\mathrm{vBm}$ or $\mathrm{vBm}^{64 \mathrm{RE}}$. The $\mathrm{vBm}^{64 \mathrm{KO}}$-infected cells displayed characteristic features of baculovirus infection, such as the VS structure (Fig. 4b), virus-induced nuclear microvesicles (Fig. 4h), the formation of preoccluded virions in the ring zone (Fig. 4e), and mature enveloped ODVs. Polyhedra were also observed in the ring zone of $\mathrm{vBm}^{64 \mathrm{KO}}$-infected cells (Fig. $4 \mathrm{~b}$ and e). The size and shape of the polyhedra in the $\mathrm{vBm}^{64 \mathrm{KO}}$-infected cells were similar to those in the $\mathrm{vBm}^{64 \mathrm{RE}}$ - or vBm -infected cells (Fig. 4a and c). Enveloped virions were detected in the polyhedra within the ring zone of the $\mathrm{vBm}^{64 \mathrm{KO}}$-infected cells (Fig. 4e), similar to the $\mathrm{vBm}^{64 \mathrm{RE}}$ - or vBm-infected cells (Fig. $4 \mathrm{~d}$ and $\mathrm{f}$ ). These observations suggested that Bm64 was not required for the formation of mature ODVs or the subsequent occlusion of ODVs into polyhedra.

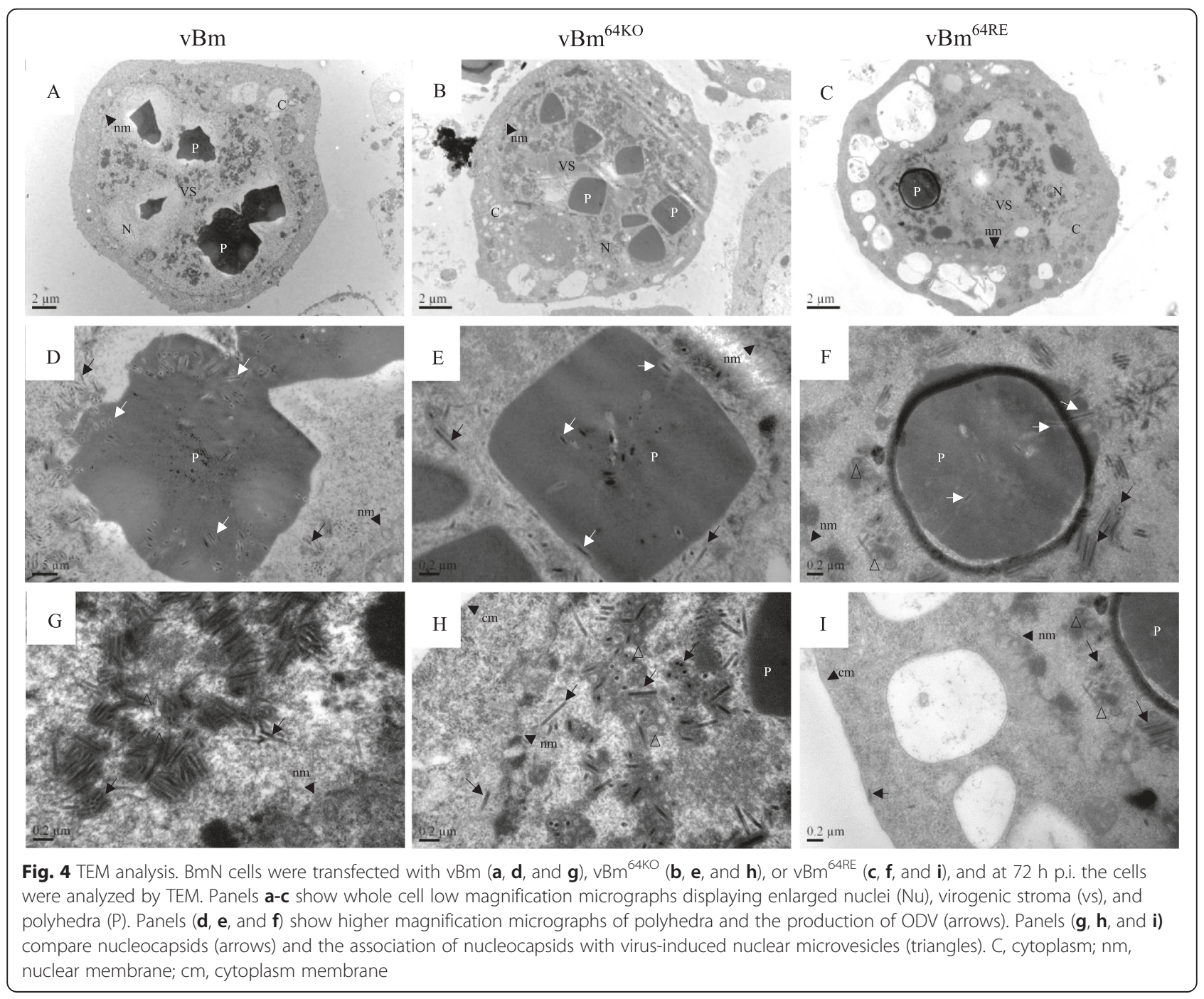




\section{Localization of Bm64 in BmNPV-infected BmN cells}

Two viruses ( $\mathrm{vBm}^{\mathrm{GFP}-\mathrm{Bm} 64}$ and $\mathrm{vBm}^{\mathrm{GFP}}$ ) were constructed to monitor the subcellular localization of Bm64 (Fig. 5a). In

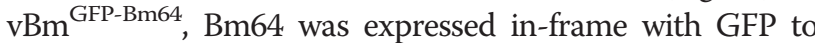
produce a GFP-Bm64 fusion protein under the control of the $B m 64$ promoter. As a control, GFP alone was expressed

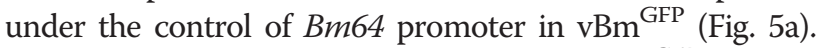
Fluorescence was detected throughout the $\mathrm{vBm}^{\mathrm{GFP}}$-infected cells (Fig. 5b). However, the fluorescence was restricted along the inner periphery (ring zone) of the nucleus in the $\mathrm{BmN}$ cells infected with vBm ${ }^{\text {GFP-Bm64 }}$ (Fig. 5b).

\section{Bm64 is required for per os infection}

To investigate whether the $B m 64$ deletion had any effect on ODV embedding, ODVs were collected from equal amounts of polyhedra $\left(1.0 \times 10^{8}\right)$ prepared from vBm-,

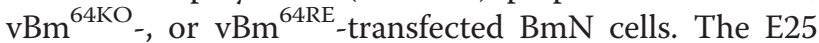
ODV envelope protein was used to detect the ODVs. The result showed that increased amounts of E25 were detected from the $\mathrm{vBm}$ and $\mathrm{vBm}^{64 \mathrm{RE}}$ polyhedra compared to the $\mathrm{vBm}^{64 \mathrm{KO}}$ polyhedra, suggesting that the deletion of Bm64 affected the ODV occlusion efficiency into polyhedra (Fig. 6a).

To examine the effect of the Bm64 deletion on the infectivity of the ODVs, the prepared polyhedra were administered to newly molted 5th instar silkworm larvae. Dosages of $5.0 \times 10^{5} \mathrm{vBm}$ and $\mathrm{vBm}^{64 \mathrm{RE}}$ polyhedra/larva resulted in a $100 \%$ mortality rate. Because the ODV occlusion level of $\mathrm{vBm}$ and $\mathrm{vBm}^{64 \mathrm{RE}}$ was approximately 7 -fold higher compared to $\mathrm{vBm}^{64 \mathrm{KO}}$ (Fig. 6b), the dosage

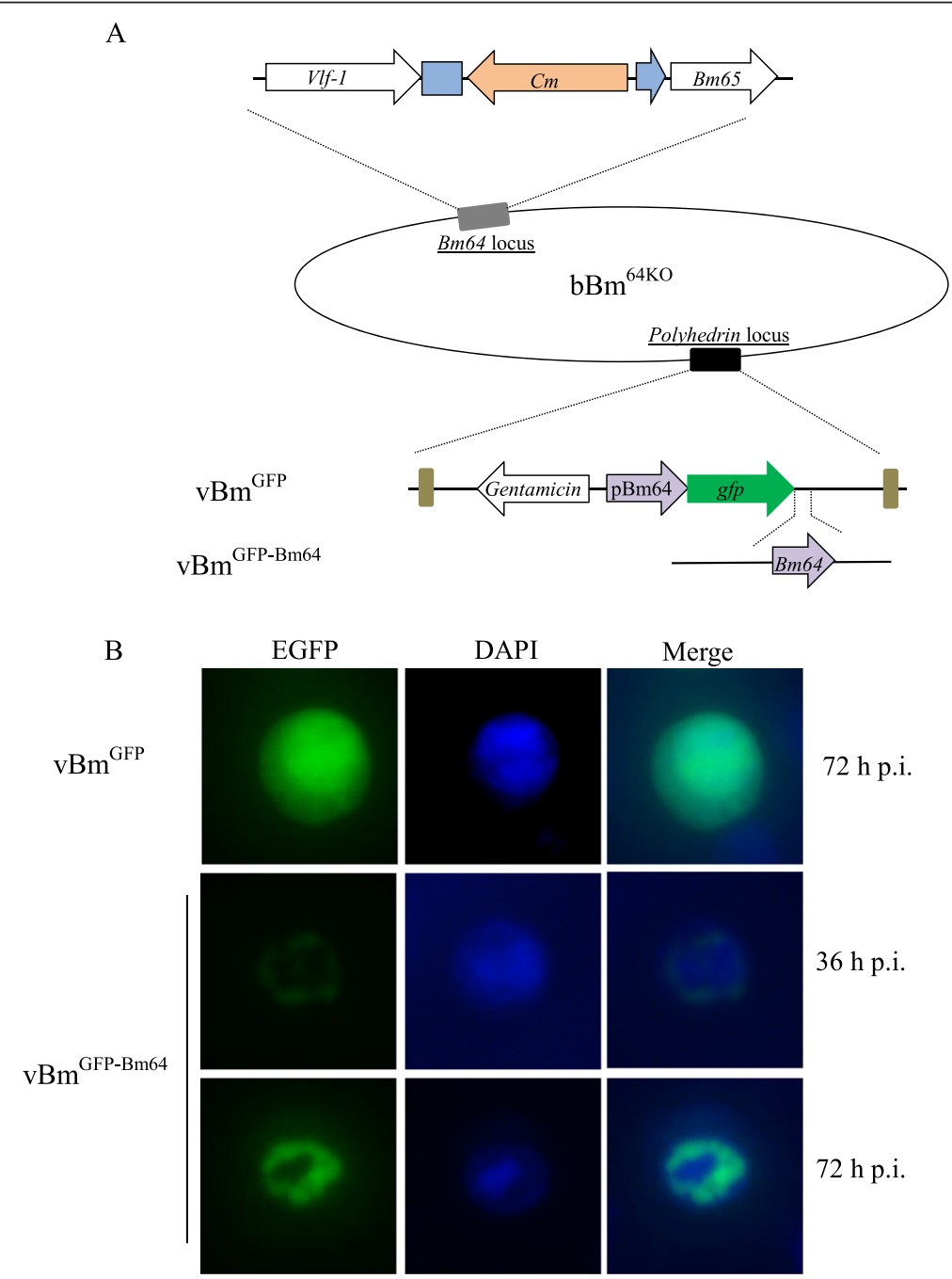

Fig. 5 Subcellular localization of the GFP-Bm64 fusion protein in BmN cells. a Schematic diagram of the construction of recombinant viruses. A gfp-bm64 chimera under the control of the polyhedrin promoter was inserted into the polh locus of the $\mathrm{BBm}^{64 \mathrm{KO}}$ bacmid to generate VBm ${ }^{\text {GFP-Bm64 }}$. The control virus VBm ${ }^{G F P}$ was constructed by transposing gfp under control of the polyhedrin promoter into the $\mathrm{VBm}^{64 \mathrm{KO}} \mathrm{bacmid}$ b Microscopy images of BmN cells infected with $v B m^{G F P-B m 64}$ and $v B m^{G F P}$. BmN cells were infected with $v B m^{G F P-B m 64}$ or $v B m^{G F P}$ at an MOI of 1 and were observed for fluorescence by laser scanning microscopy at 36 or $72 \mathrm{~h} \mathrm{p.i}$ 


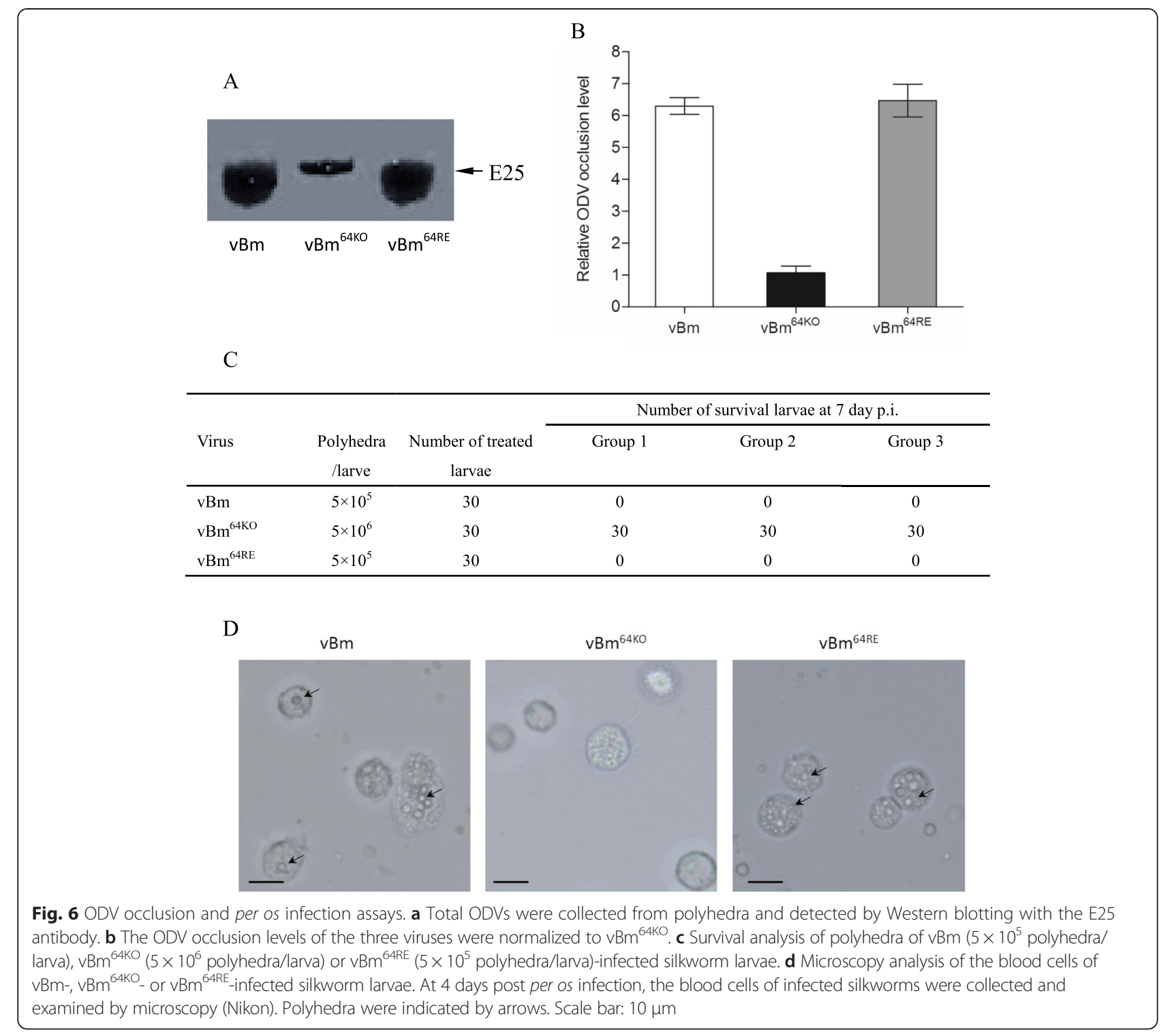

for $\mathrm{vBm}^{64 \mathrm{KO}}$ was $5.0 \times 10^{6}$ polyhedra/larva. However, ingestion of the polyhedra from $\mathrm{vBm}^{64 \mathrm{KO}}$ did not result in death (Fig. 6c). The blood examination results showed that polyhedra were detected in both the $\mathrm{vBm}$ - and $\mathrm{vBm}^{64 \mathrm{RE}}$-infected larvae. In contrast, no polyhedra were detected in the blood cells of the $\mathrm{vBm}^{64 \mathrm{KO}}$-infected larvae (Fig. 6d). These results indicated that Bm64 was required for BmNPV oral infection.

\section{Discussion}

All baculoviruses sequenced to date contained homologues of 37 core genes, suggesting that these genes performed key functions in the baculovirus life cycle $[8,18,19]$. In this study, we investigated the role of a recently identified core gene (BmNPV Bm64). We found that Bm64 played important roles in BV production and per os infection but was not required for viral genome replication or mature ODV formation.

Homologues of Bm64 are found in all baculoviruses, suggesting that this protein is required for a function utilized by all members of the Baculoviridae [20]. A Bm64 homologue was detected in the envelope of both ODVs and BVs [10]. At least 5 other proteins in addition to Bm64 are specifically localized to the envelopes of BVs and ODVs, including Ubiquitin, Ac68, E25, PIF-4, and E18 [10]. BV production and ODV formation are not affected by the deletion Ac68 and PIF-4 [21, 22]. In contrast, a ubiquitin mutant virus caused a 5-10-fold reduction in BV production, and E25 and E18 were required for efficient BV production and ODV formation [16, 23].

The role of $B m 64$ in the context of BmNPV infection in $\mathrm{BmN}$ cells was analyzed using the Bm64 knockout 
bacmid. End-point dilution and qPCR assays demonstrated that $\mathrm{vBm}^{64 \mathrm{KO}}$ had a defect in BV production. Electron microscopy showed that nucleocapsids produced by $\mathrm{vBm}^{64 \mathrm{KO}}$ were morphologically indistinguishable from those observed for either $\mathrm{vBm}$ or $\mathrm{vBm}^{64 \mathrm{RE}}$ (Fig. 4), and mature enveloped ODVs were found in $\mathrm{vBm}^{64 \mathrm{KO}}$-transfected cells. These results indicated that Bm64 played an important role in $\mathrm{BV}$ production but was not required for the formation of mature ODVs.

After nucleocapsids replicate in the nuclei of infected cells, they need to exit in order to spread the infection. They have been suggested to rapidly egress from the nucleus to the cytoplasm and obtain the envelope from the cytoplasmic membrane [18]. Many viral proteins were shown to be essential for this process. Some were required for the egress of the nucleocapsids from the nucleus (e.g., Ac66 [24] and Ac88 [25]). Others that were not required for nucleocapsid egress from the cells affected the viral titer (e.g., Ac109 [26] and Ac34 [27]). Finally, some genes were involved in the transfer of the nucleocapsids to the cytoplasm (e.g., P78/83 [28]). During the baculovirus infection cycle, nucleocapsids undergo intracellular motility driven by actin polymerization; the motility requires at least the viral $\mathrm{P} 78 / 83$ protein and the host Arp2/3 complex [28].

The subcellular localization of Bm64 demonstrated that this protein was primarily distributed in the ring zone of infected nuclei during viral infection (Fig. 5). A recent study demonstrated that $a c 78$ was required for nucleocapsid egress from the nucleus [12]. Many proteins are localized to the ring zone of infected nuclei, such as Ac76 [29], P33 [13], Ac93 [19], and E25 [30]. The ring zone is very important for nucleocapsid envelopment and egress from the nucleus. Ac78 was demonstrated to interact with P33 in the ring zone; both Ac78 and P33 are BV envelope components, suggesting that BVs obtain these ring zone-localized proteins from the nucleus [13]. The ODV envelope proteins P74, PIF-1, PIF-2, and PIF-3 form a complex on the ODV envelope [31] and are not required for ODV formation and ODV embedding into polyhedra [32], indicating that these proteins are nonessential for the recognition between nucleocapsids and intranuclear microvesicles or between ODVs and polyhedra. Consistent with the previous study, per os infectivity assays demonstrated that Bm64 was required for the BmNPV oral infection process, indicating that Bm64 played an important role in ODV primary infection [11].

Our results agree with the findings of $\mathrm{Li}$ et al. that $a c 78$ (Bm64 homolog) plays an important role in BV production efficient ODV occlusion [11]. However, deletion of $a c 78$ resulted in a more severe defect for AcMNPV BV infection. A comparison of the predicted amino acid sequences of Bm64 homologues showed that the conservation was very low (Additional file 2: Figure S1) [13], suggesting that the functions of Bm64 homologues during viral infection might differ. The characteristics of baculovirus core genes were demonstrated to be conserved, but they might have different functions in the viral infection cycles.

\section{Conclusion}

In conclusion, this study demonstrates that deletion of Bm64 affects BV production and ODV infectivity but does not affect ODV formation. Although the exact function of Bm64 in nucleocapsid egress from the nucleus and ODV formation is still unclear, our study has provided valuable insight into the baculovirus life cycle.

\section{Methods}

Bacmid, virus, and cells

The E. coli strains BW25113 containing the plasmid pKD46 and BW25141 harboring the plasmid pKD3 (encoding the chloramphenicol resistance gene) were kindly provided by Mary Berlyn (Yale university). The E. coli strain $\mathrm{DH} 10 \mathrm{H}$ (containing a helper plasmid pMON7124) and DH10BmBac (containing a BmNPV bacmid and a helper plasmid pMON7124) were constructed previously in our lab [33]. BmN cells were cultured at $27{ }^{\circ} \mathrm{C}$ in $\mathrm{TC}-100$ insect medium supplemented with $10 \%$ fetal calf serum (Gibco, USA).

\section{Total RNA preparation, RT-PCR and 5' rapid amplification of CDNA ends (5'RACE) analysis}

$\mathrm{BmN}$ cells were infected with BmNPV at a multiplicity of infection (MOI) of $550 \%$ tissue culture infective doses $\left(\mathrm{TCID}_{50}\right)$. At various time points post-infection (p.i.), total cellular RNA was isolated according to the manufacturer's instructions (RNeasy mini kit, Qiagen, Germany). Reverse transcription-PCR (RT-PCR) was performed with an EasyScript First-Strand cDNA Synthesis SuperMix kit (Transgen, China) using $2.0 \mu \mathrm{g}$ of total RNA as the template for each time point. Synthesis of first-strand DNA complementary to the mRNA (cDNA) was performed using the avian myeloblastosis virus reverse transcriptase and oligo $(\mathrm{dT})$ primers according to the manufacturer's instructions. The Bm64-specific primers Bm64F (5'-ATGAATTTGGACGTGCCATAC-3') and Bm64-R (5'-CTCGATTAACCACAATGAACGTCTAGAGC-3') were used for PCR amplification to detect the Bm64 transcripts.

To characterize Bm64, its temporal expression was examined by $5^{\prime}$ RACE analysis. The 5'RACE procedure was performed using the Smarter ${ }^{\mathrm{TM}}$ RACE cDNA Amplification Kit (Clontech, USA) with $1 \mu \mathrm{g}$ of purified total RNA isolated from BmNPV-infected cells at $48 \mathrm{~h}$ p.i.. A Bm64-specific primer (Bm64-RACE, 5'-GCTTGCTC CTGTTTGAGTTCAG-3') was used for cDNA synthesis and PCR amplification following the manufacturer's 
instructions. The PCR products were gel purified and cloned into the pGEMT-easy vector (Promega, Madison, USA).

\section{Generation of the Bm64-knockout BmNPV bacmid}

A Bm64-knockout BmNPV bacmid was generated as previously described [16]. A chloramphenicol resistance gene $(\mathrm{Cm})$ was amplified using Bm64KO-F (5'- GACAC GTTGCTCGTCGTGTTGTTATAGCCCACCATCATG TCGTCTATTGGGTGTAGGCTGGAGCTGCT-3’) and Bm64KO-R (5'- ACATGAATTTGGACGTGCCATAC TATCGGTTGGGCAACCACGAAAAGTGACATATGA

ATATCCTCCTTAG -3') with pKD3 as the template. These primers contained 50 and 47 bp sequences homologous to the upstream and downstream flanking regions (underlined sequences) of Bm64, respectively; a stop codon (black box) was also introduced. The $\mathrm{Cm}$ cassette PCR fragment was gel purified using a QIAquick PCR purification kit (Qiagen, USA) and electroporated into E. coli BW25113 cells containing the BmNPV bacmid. The electroporated cells were incubated at $37{ }^{\circ} \mathrm{C}$ for $3 \mathrm{~h}$ in $1 \mathrm{ml}$ of SOC medium (2\% Bacto tryptone, $0.5 \%$ Bacto yeast extract, $10 \mathrm{mM} \mathrm{NaCl}, 2.5 \mathrm{mM} \mathrm{KCl}, 10 \mathrm{mM}$ $\mathrm{MgCl}_{2}, 10 \mathrm{mM} \mathrm{MgSO}$, and $20 \mathrm{mM}$ glucose) and plated onto agar medium containing $7 \mu \mathrm{g} / \mathrm{ml}$ chloramphenicol and $50 \mu \mathrm{g} / \mathrm{ml}$ kanamycin. The plates were incubated at $37^{\circ} \mathrm{C}$ overnight. Colonies resistant to both chloramphenicol and kanamycin were selected and confirmed with the primers Bm64-R (5'- CTCGATTAACCACAATGAACG TCTAGAGC -3') and Cm-F (5'-TTGTTACACCGTTTT CCATGAGC-3') to detect the correct insertion of the $\mathrm{Cm}$ in the region of the Bm64 locus.

The recombinant bacmids confirmed by PCR and sequencing were selected and designated $\mathrm{bBm}^{64 \mathrm{KO}}$. The identified $\mathrm{bBm}^{64 \mathrm{KO}}$ was extracted and electro-transformed into E. coli $\mathrm{DH} 10 \mathrm{BH}$ to generate $\mathrm{DH} 10 \mathrm{Bm}^{64 \mathrm{KO}}$ cells containing both the Bm64-deleted bacmid and the helper plasmid.

\section{Construction of the Bm64 knockout, repair, and positive control BmNPV bacmids}

The Bm64 knockout, the repair and the positive control BmNPV bacmids containing polyhedrin and gfp (enhanced green fluorescence protein gene) were constructed by site-specific transposition as previously described [34]. The pFast-PH-GFP (containing polyhedrin and $g f p$ ) was constructed as described and transformed into electrocompetent $\mathrm{DH} 10 \mathrm{BmBac}$ or $\mathrm{DH} 10 \mathrm{Bm}^{64 \mathrm{KO}}$ cells to generate the $B m 64$ knockout bacmid $\left(\mathrm{vBm}^{64 \mathrm{KO}}\right)$ or the positive control bacmid ( $\mathrm{vBm})$, respectively.

To construct a repair bacmid $\left(\mathrm{vBm}^{64 \mathrm{RE}}\right)$, a 531 bp fragment containing the Bm64 gene with its native promoter was amplified using the primers Bm64RE-F (5'-GAAGG
CCTCAAGTGTTTGCGCAACGCAAC-3') and Bm64RER (5'-GCTCTAGACGTTCATTGTGGTTAATCGAG-3'). The repair fragments were cloned into the pFast-PH-GFP plasmid to generate pFast-PH-Bm64RE-GFP. pFast-PHBm64RE-GFP was used to transpose the parental knockout bacmids to generate the $B m 64$ repair bacmid ( $\left.\mathrm{vBm}^{64 \mathrm{RE}}\right)$. To confirm $\mathrm{vBm}^{64 \mathrm{RE}}$ by PCR, we used the primer Bm64CF-R (5'-GTTCGCTGGTGATATCATCGTTGAG -3') located in the deletion sequence of $\mathrm{vBm}^{64 \mathrm{KO}} \cdot \mathrm{vBm}^{64 \mathrm{RE}}$ was confirmed with Bm64RE-F/Bm64CF-R. Bacmid DNA was extracted and quantified as described previously [35].

\section{Viral growth curve analysis and plaque assay}

BmN cells $\left(1.0 \times 10^{6}\right)$ were transfected with $1.0 \mu \mathrm{g}$ of each bacmid (vBm, vBm ${ }^{64 K O}$, or $\mathrm{vBm}^{64 \mathrm{RE}}$ ). At 36 and 96 h p.t., the progression of viral infection was monitored by fluorescence microscopy. A viral plaque assay was performed as previously described [36]. Briefly, $\mathrm{BmN}$ cells were plated at a density of $1 \times 10^{6}$ cells/35-mm-diameter well of a six-well plate. The cells were transfected with $10 \mathrm{ng}$ of $\mathrm{vBm}, \mathrm{vBm}^{64 \mathrm{KO}}$, or $\mathrm{vBm}^{64 \mathrm{RE}}$ bacmid DNA. Then, the monolayers were overlaid with $1 \%$ low-melting-point agarose for cell culture (Gibco, USA) in complete Grace's medium. The plaques were photographed and measured 72 h p.t..

\section{Analysis of the viral growth curve}

To evaluate the viral replication of $\mathrm{vBm}, \mathrm{vBm}^{64 \mathrm{KO}}$, and $\mathrm{vBm}^{64 \mathrm{RE}}, \mathrm{BmN}$ cells were infected in triplicate with each virus $\left(\mathrm{vBm}, \mathrm{vBm}^{64 \mathrm{KO}}\right.$, or $\left.\mathrm{vBm}^{64 \mathrm{RE}}\right)$ at an MOI of 3 . After $1 \mathrm{~h}$ of incubation, the cells were washed twice and the medium was replaced with fresh TC100 medium. Supernatants were collected at the indicated time points $(6,12,24,48,72$, and 96 h p.i.), and the titers were determined by an end point dilution assay on BmN cells.

TCID $_{50}$ was used to determine the infectious virions, whereas quantitative real-time PCR (qPCR) was performed to confirm the baculovirus stocks as previously described [37]. Briefly, an aliquot of each supernatant $(250 \mu \mathrm{l})$ was processed using a viral DNA kit (Omega, USA). A $2.0 \mu \mathrm{l}$ aliquot of each purified DNA sample was mixed with $10 \mu \mathrm{l}$ of $\mathrm{SYBR}^{\odot}$ Premix ExTaq (TaKaRa, Japan) and the qPCR primers in a $20 \mu \mathrm{l}$ reaction volume. The PCR was performed using the 7300 Real-Time PCR system (ABI, USA) under the following conditions: $95^{\circ} \mathrm{C}$ for $30 \mathrm{~s}$ and 45 cycles of $95^{\circ} \mathrm{C}$ for $5 \mathrm{~s}$ and $60{ }^{\circ} \mathrm{C}$ for $31 \mathrm{~s}$.

\section{Quantitative real-time PCR (qPCR) DNA replication assay}

To detect viral DNA replication, a qPCR assay was performed as previously described [38]. BmN cells were infected with $\mathrm{vBm}, \mathrm{vBm}^{64 \mathrm{KO}}$, or $\mathrm{vBm}^{64 \mathrm{RE}}$ at an MOI of 1 and harvested at different time points. Total DNA was extracted with the Classic Genomic DNA Isolation Kit (Sangon, Canada). Q-PCR was performed with a $500 \mathrm{nM}$ 
concentration of each primer using the 7300 Real-Time PCR system (ABI, USA) under the following conditions: $95{ }^{\circ} \mathrm{C}$ for $30 \mathrm{~s}$ and 45 cycles of $95{ }^{\circ} \mathrm{C}$ for $5 \mathrm{~s}$ and $60{ }^{\circ} \mathrm{C}$ for $31 \mathrm{~s}$.

\section{Transmission electron microscopy (TEM)}

$\mathrm{BmN}$ cells $\left(5 \times 10^{6}\right.$ cells) were infected with $\mathrm{vBm}, \mathrm{vBm}^{64 K O}$, or $\mathrm{vBm}^{64 \mathrm{RE}}$ at an MOI of 5 . At the indicated time point post-infection, the cells were collected and centrifuged at $5000 \mathrm{rpm}$ for $5 \mathrm{~min}$. Then, the cells were fixed, dehydrated, embedded, sectioned, and stained as previously described [16]. The samples were visualized with a TEM Model JEM1230 at an accelerating voltage of $120 \mathrm{kV}$.

\section{Construction of GFP fusion recombinant bacmids and microscopy determination}

To monitor the localization of Bm64 in BmNPVinfected BmN cells, GFP was fused at the N-terminus of Bm64 under the control of the Bm64 promoter (pBm64) to create a GFP-Bm64 fusion protein. A recombinant fusion bacmid ( $\left(\mathrm{vBm}^{\mathrm{GFP}-\mathrm{Bm} 64}\right)$ and a control bacmid $\left(\mathrm{vBm}^{\mathrm{GFP}}\right)$ were constructed as previously described [30]. The Bm64 promoter was PCR-amplified using the primers Bm64pro-F (5'-GACCATGGCAAGTGTTTGCGCAACG CAAC-3') and Bm64pro-R (5'-CGGAATTCCCACGTCCAAATTCATGTTTACAAC-3'). The enhanced green fluorescent protein (egfp) was amplified with the primers EGFP-F (5'-AAGCTTCGCCACCATGGTGAGCAAG-3') and EGFP-R (5'-GGTACCCTTGTACAGCTCGTCCAT G-3'), while Bm64 was amplified with Bm64-F (5'-GGTA CCATGAATTTGGACGTGCCATAC-3') and Bm64-R (5'- AAGCTTCGTTCATTGTGGTTAATCGAG -3'). BmN cells $\left(1 \times 10^{6}\right)$ were transfected with $1 \mu \mathrm{g}$ of $\mathrm{vBm}^{\mathrm{GFP}-}$ ${ }^{\mathrm{Bm} 64}$ or $\mathrm{vBm}{ }^{\mathrm{GFP}}$ DNA. At 96 h p.t., the supernatants were collected, and the BV titers were determined by an endpoint dilution assay. For microscopy analysis, $\mathrm{BmN}$ cells $\left(5 \times 10^{5}\right)$ were infected with $\mathrm{vBm}^{\mathrm{GFP}-\mathrm{Bm} 64}$ or $\mathrm{vBm}^{\mathrm{GFP}}$ at an MOI of 1 . At 36 and $72 \mathrm{~h}$ p.i., the cells were examined with a microscope to analyze the GFP fluorescence.

\section{Purification of ODVs for western blot analysis}

The polyhedra were prepared from the infected cells as previously described [31]. Polyhedra were suspended in DAS buffer $\left(0.1 \mathrm{M} \mathrm{Na}_{2} \mathrm{CO}_{3}, 166 \mathrm{M} \mathrm{NaCl}\right.$, and $10 \mathrm{mM}$ EDTA, $\mathrm{pH}$ 10.5), and the solution was neutralized with $0.5 \mathrm{M}$ Tris- $\mathrm{HCl}$ ( $\mathrm{pH} 7.5)$. After removing the insoluble debris, the ODVs were collected by centrifugation at $50,000 \times \mathrm{g}$ for $60 \mathrm{~min}$ at $4{ }^{\circ} \mathrm{C}$ and resuspended in $0.1 \times \mathrm{TE}$ at $4{ }^{\circ} \mathrm{C}$.

Protein samples were separated by SDS-polyacrylamide gel electrophoresis (PAGE) with a $12 \%$ acrylamide separating gel. For Western blot analysis, the gels were electroblotted onto nitrocellulose (NC) membranes. Proteins on the membranes were blocked in $25 \mathrm{mM}$ Tris-base
(pH 7.4) with $140 \mathrm{mM} \mathrm{NaCl}, 2.7 \mathrm{mM} \mathrm{KCl}, 0.05 \%$ Tween20 (TBS-T) and $5 \%$ milk. For immune detection, the membranes were incubated for $2 \mathrm{~h}$ at room temperature with the primary anti-E25 rabbit polyclonal antibody (1:1000). The secondary antibody was added, and the blots were incubated for $2 \mathrm{~h}$ prior to three washes in TBS-T. The secondary goat anti-rabbit IgG antibody conjugated with horseradish peroxidase (Amersham Biosciences, Germany) was diluted 1:2000 in TBS-T with $5 \%$ milk. Blots were detected using an enhanced chemiluminescence system (ECL; Thermo, USA) according to the manufacturer's instructions and analyzed with Image J (http://rsb.info.nih.gov/ij).

\section{In vivo infectivity assays}

The infectivity of the ODVs in vivo was examined by orally inoculating newly molted 5th instar Bombyx mori larvae with the polyhedra of $\mathrm{vBm}, \mathrm{vBm}^{64 \mathrm{KO}}$, or $\mathrm{vBm}^{64 \mathrm{RE}}$. The polyhedra were purified from transfected $\mathrm{BmN}$ cells, and the oral infectivity bioassays were performed as previously described [22]. A cohort of 30 larvae was used for each treatment, and the treatment was repeated in triplicate. Infected larvae were reared with fresh mulberry until all larvae pupated or died. At 4 days post-molt, the blood of the Bombyx mori larvae was collected and observed under a microscope to detect the virus infection.

\section{Additional files}

Additional file 1: Table S1. Comparison the roles of Bm64 homologs. (DOCX $16 \mathrm{~kb}$ )

Additional file 2: Figure S1. Amino acid sequence aligment of 12 Bm64 homologs. (DOCX $253 \mathrm{~kb}$ )

\section{Competing interests}

The authors declare that they have no competing interests.

\section{Authors' contributions}

LC performed the molecular genetic studies and drafted the manuscript. YS participated in the sequence alignment and performed the virus replication assays. RY and WH participated in the TEM assays. XW participated in the design of the study and performed the statistical analysis. GS conceived of the study, participated in its design and coordination and helped to draft the manuscript. All authors read and approved the final manuscript.

\section{Acknowledgements \\ This work was supported by Natural Science Foundation of China (31402140), the State Key Laboratory Breeding Base for Zhejiang Sustainable Pest and Disease Control (2010DS700124-KF1405), the China Postdoctoral Science Foundation (2014 M560496), and the Shaoxing 330 Overseas Elites Program to Guoxin Shen.}

\section{Author details}

'Sericultural Research Institute, Zhejiang Academy of Agricultural Sciences, Hangzhou 310021, China. 'Lab of Silkworm Biotechnology, College of Animal Sciences, Zhejiang University, Hangzhou 310058, China. 


\section{References}

1. Jehle JA, Blissard GW, Bonning BC, Cory JS, Herniou EA, Rohrmann GF, et al. On the classification and nomenclature of baculoviruses: a proposal for revision. Arch Virol. 2006;151:1257-66.

2. Volkman LE, Summers MD. Autographa californica nuclear polyhedrosis virus: comparative infectivity of the occluded, alkali-liberated, and nonoccluded forms. J Invertebr Pathol. 1977;30:102-3.

3. Volkman LE, Summers MD, Hsieh CH. Occluded and nonoccluded nuclear polyhedrosis virus grown in Trichoplusia ni: comparative neutralization comparative infectivity, and in vitro growth studies. J Virol. 1976;19:820-32.

4. Granados RR, Lawler KA. In vivo pathway of Autographa californica baculovirus invasion and infection. Virology. 1981;108:297-308.

5. Keddie BA, Aponte GW, Volkman LE. The pathway of infection of Autographa californica nuclear polyhedrosis virus in an insect host. Science. 1989;243:1728-30.

6. van Oers MM, Vlak JM. Baculovirus genomics. Curr Drug Targets. 2007:8:1051-68.

7. Liu JC, Maruniak JE. Molecular characterization of genes in the GP41 region of baculoviruses and phylogenetic analysis based upon GP41 and polyhedrin genes. Virus Res. 1999;64:187-96.

8. Garavaglia MJ, Miele SA, Iserte JA, Belaich MN, Ghiringhelli PD. The ac53, ac78, ac101, and ac103 Genes Are Newly Discovered Core Genes in the Family Baculoviridae. J Virol. 2012;86:12069-79.

9. Cohen DPA, Marek M, Davies BG, Vlak JM, Oers MM. Encyclopedia of Autographa californica Nucleopolyhedrovirus Genes. Virologica Sinica. 2009;24:359-414

10. Hou D, Zhang L, Deng F, Fang W, Wang R, Liu X, et al. Comparative Proteomics Reveal Fundamental Structural and Functional Differences between the Two Progeny Phenotypes of a Baculovirus. J Virol. 2013;87:829-39.

11. Li SN, Wang JY, Yuan MJ, Yang K. Disruption of the baculovirus core gene ac78 results in decreased production of multiple nucleocapsid-enveloped occlusion-derived virions and the failure of primary infection in vivo. Virus Res. 2014;191:70-82.

12. Tao XY, Choi JY, Kim WJ, Lee JH, Liu Q, Kim SE, et al. The Autographa californica multiple nucleopolyhedrovirus ORF78 is essential for budded virus production and general occlusion body formation. J Virol. 2013;87:8441-50.

13. Huang $\mathrm{H}$, Wang $M$, Deng $F$, Hou D, Arif BM, Wang $\mathrm{H}$, et al. The ha72 core gene of baculovirus is essential for budded virus production and occlusionderived virus embedding, and amino acid K22 plays an important role in its function. J Virol. 2014;88:705-9.

14. Ono C, Kamagata T, Taka H, Sahara K, Asano S, Bando H. Phenotypic grouping of 141 BmNPVs lacking viral gene sequences. Virus Res. 2012;165:197-206.

15. Chen YR, Zhong S, Fei Z, Hashimoto Y, Xiang JZ, Zhang S, et al. The transcriptome of the baculovirus Autographa californica multiple nucleopolyhedrovirus in Trichoplusia ni cells. J Virol. 2013;87:6391-405.

16. Chen L, Hu X, Xiang X, Yu S, Yang R, Wu X. Autographa californica multiple nucleopolyhedrovirus odv-e25 (Ac94) is required for budded virus infectivity and occlusion-derived virus formation. Arch Virol. 2012;157:617-25.

17. McCarthy CB, Dai X, Donly C, Theilmann DA. Autographa californica multiple nucleopolyhedrovirus ac142, a core gene that is essential for BV production and ODV envelopment. Virology. 2008;372:325-39.

18. Rohrmann GF. Baculovirus molecular biology. Bethesda (MD): National Center for Biotechnology Information (US); 2011.

19. Yuan M, Huang Z, Wei D, Hu Z, Yang K, Pang Y. Identification of Autographa californica nucleopolyhedrovirus ac93 as a core gene and its requirement for intranuclear microvesicle formation and nuclear egress of nucleocapsids. J Virol. 2011;85:11664-74.

20. Herniou EA, Olszewski JA, Cory JS, O'Reilly DR. The genome sequence and evolution of baculoviruses. Annu Rev Entomol. 2003;48:211-34.

21. Xu HJ, Yang ZN, Zhao JF, Tian CH, Ge JQ, Tang XD, et al. Bombyx mori nucleopolyhedrovirus ORF56 encodes an occlusion-derived virus protein and is not essential for budded virus production. J Gen Virol. 2008;89:1212-9.

22. Fang $M$, Nie $Y$, Harris S, Erlandson MA, Theilmann DA. Autographa californica multiple nucleopolyhedrovirus core gene ac96 encodes a per Os infectivity factor (PIF-4). J Virol. 2009;83:12569-78.

23. McCarthy CB, Theilmann DA. AcMNPV ac143 (odv-e18) is essential for mediating budded virus production and is the 30th baculovirus core gene. Virology. 2008;375:277-91.

24. Ke J, Wang J, Deng R, Wang X. Autographa californica multiple nucleopolyhedrovirus ac66 is required for the efficient egress of nucleocapsids from the nucleus, general synthesis of preoccluded virions and occlusion body formation. Virology. 2008;374:421-31.

25. Shen $\mathrm{H}$, Chen K. BM61 of Bombyx mori nucleopolyhedrovirus: its involvement in the egress of nucleocapsids from the nucleus. FEBS Lett. 2012;586:990-5.

26. Fang M, Nie $Y$, Theilmann DA. Deletion of the AcMNPV core gene ac109 results in budded virions that are non-infectious. Virology. 2009;389:66-74.

27. Cai Y, Long Z, Qiu J, Yuan M, Li G, Yang K. An ac34 deletion mutant of Autographa californica nucleopolyhedrovirus exhibits delayed late gene expression and a lack of virulence in vivo. J Virol. 2012;86:10432-43.

28. Ohkawa T, Volkman LE, Welch MD. Actin-based motility drives baculovirus transit to the nucleus and cell surface. J Cell Biol. 2010;190:187-95.

29. Hu Z, Yuan M, Wu W, Liu C, Yang K, Pang Y. Autographa californica multiple nucleopolyhedrovirus ac76 is involved in intranuclear microvesicle formation. J Virol. 2010;84:7437-47.

30. Chen L, Yang R, Hu X, Xiang X, Yu S, Wu X. The formation of occlusionderived virus is affected by the expression level of ODV-E25. Virus Res. 2013.

31. Peng K, van Oers MM, Hu Z, van Lent JW, Vlak JM. Baculovirus per os infectivity factors form a complex on the surface of occlusion-derived virus. J Virol. 2010;84:9497-504.

32. Li X, Song J, Jiang T, Liang C, Chen X. The N-terminal hydrophobic sequence of Autographa californica nucleopolyhedrovirus PIF-3 is essential for oral infection. Arch Virol. 2007;152:1851-8.

33. Cao C, Wu X, Zhao N, Yao H, Lu X, Tan Y. Development of a rapid and efficient BmNPV baculovirus expression system for application in mulberry silkworm, Bombyx mori. Current Science. 2006;91:1692-7.

34. Zhang MJ, Cheng RL, Lou YH, Ye WL, Zhang T, Fan XY, et al. Disruption of Bombyx mori nucleopolyhedrovirus ORF71 (Bm71) results in inefficient budded virus production and decreased virulence in host larvae. Virus Genes. 2012;45:161-8.

35. Wang L, Salem TZ, Campbell DJ, Turney CM, Kumar CM, Cheng XW. Characterization of a virion occlusion-defective Autographa californica multiple nucleopolyhedrovirus mutant lacking the $p 26, p 10$ and $p 74$ genes J Gen Virol. 2009;90:1641-8.

36. de Jong J, Arif BM, Theilmann DA, Krell PJ. Autographa californica multiple nucleopolyhedrovirus me53 (ac140) is a nonessential gene required for efficient budded-virus production. J Virol. 2009;83:7440-8.

37. Lo HR, Chao YC. Rapid titer determination of baculovirus by quantitative real-time polymerase chain reaction. Biotechnol Prog. 2004;20:354-60.

38. Vanarsdall AL, Okano K, Rohrmann GF. Characterization of a baculovirus with a deletion of vlf-1. Virology. 2004;326:191-201.

\section{Submit your next manuscript to BioMed Central and take full advantage of:}

- Convenient online submission

- Thorough peer review

- No space constraints or color figure charges

- Immediate publication on acceptance

- Inclusion in PubMed, CAS, Scopus and Google Scholar

- Research which is freely available for redistribution 